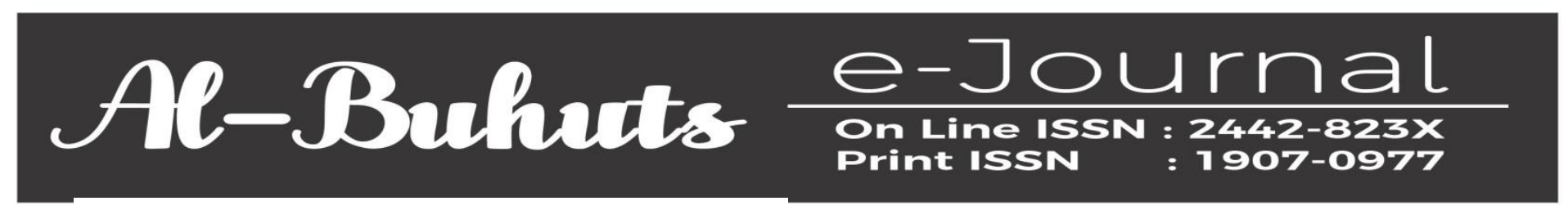

Volume 15 Nomor 2, Desember 2019

\title{
Implementasi Peraturan Daerah Nomor 36 Tahun 2011 Tentang Izin Mendirikan Bangunan dalam Peningkatan Pendapatan Asli Daerah Kota Gorontalo
}

\author{
Noviyanti Tue \\ Universitas Ichsan Gorontalo \\ Noviyantitue29@gmail.com
}

\begin{abstract}
The Research Aims To Investigate (1) Strategi Of Regional Regulation Implentation No. 26 Of 2011 About Building Permit Improvement Of Local Government Revenue Of Gorontalo City (2) Factor Determining Succes Of Regional Regulation Implementation No. 36 Of 2011 About Bulding Permit And Improvement Of Local Government Revenue Of Gorontalo City (3) Optimization Effort Of Regional Regulation Implementation No. 36 Of 2011 About Building Permit Improvement Of Local Government Revenue. It Applies Qualitative Approach By Having Primary Data As Data Source And They Are Obtained Trhough Interview. Technique Of Analyzing The Data Applies Miles \& Huberman Interactive Model. Research Finding Are (1) Overall, Implementation Of Regional Regulation No. 36 Of 2011 About Building Permit In Improvement Of Local Government Revenue Of Gorontalo City Has Been Good, Yet An Improvement Is Required Particulary At Its Service That May Decrease People Obedience As Well As Well As The Sanction Should Be More Assertive To Create Deterrent Effect. (2) Strategy In The Implementation Of Regional Regulation No.36 Of 2011 About Building Permit In Improvement Of Local Government Revenue Of Gorontalo City Are Stable Strategy If The Service, Retribution Collection, Supervision And Sanction Impact Retribution Of Building Permit Paying Obedience And Diversification Strategy If The Service, Retribution, Collection Supervision, And Sanction Are Not Optium. (3) Facto Determining Succes Implementation Of Regional Regulation No. 36 Of 2011 About Building Permit In Improvement Of Local Government Revenue Off Gorontalo City Comprise Comunication, Resource, Disposition, Or Atitude Of Implementer And Structure Of Bureaucracy.(4) Problem On Implementation Of Regional Regulation No.36 Of 2011 About Building Permit Improvement Of Local Government Revenuecan Be Solved Through Two Ways Namely Intensification And Extensification.
\end{abstract}

Keyword: Regional Regulation No.36 of 2011 of Gorontalo City

\section{A. PENDAhULUAN}

Pemerintah Kota Gorontalo dalam keberadaannya sebagai salah satu daerah otonom menuju pemerintahan daerah yang mandiri berdasarkan semangat otonomi daerah melakukan pembenahan disemua lini pemerintahan termasuk di dalamnya birokrasi pelayanan khususnya pada pelayanan Izin Mendirikan Bangunan (IMB). Begitu banyak kebijakan yang dikeluarkan oleh Pemerintah Kota Gorontalo salah satunya adalah kebijakan mengenai perda nomor 36 tahun 2011 tentang retribusi Izin Mendirikan Bangunan sebagai tujuan untuk peningkatan sumber Pendapatan Asli Daerah Kota Gorontalo. 
Melalui penerapan Peraturan Daerah Nomor 36 tahun 2011 mengenai IMB Kota Gorontalo dijelaskan juga bahwa dengan adanya IMB pemerintah daerah Kota Gorontalo dapat mengontrol dalam rangka pendataan fisik kota sebagai dasar yang sangat penting bagi perencanaan, pengawasan dan penertiban pembangunan kota yang terarah dan sangat bermanfaat pula bagi pemilik bangunan. Dengan memperhatikan berbagai penjelasan di atas, maka diharapkan setiap pembangunan yang dilaksanakan harus memiliki IMB dan benarbenar memanfaatkan ruang yang aman dan nyaman dalam rangka untuk mendukung terlaksananya pembangunan perkotaan.

Selanjutnya Izin Mendirikan Bangunan (IMB) berlaku pula untuk bangunan rumah tinggal lama yaitu bangunan rumah yang keberadaannya secara fisik telah lama berdiri tanpa atau belum ber-IMB. Selain untuk rumah tinggal, izin mendirikan bangunan juga berlaku untuk bangunan-bangunan dengan fungsi yang lain seperti gedung perkantoran, gedung industri, dan bangunan fasilitas umum. Izin mendirikan bangunan memiliki dasar hukum yang harus dipatuhi sehingga mutlak harus dimiliki setiap orang yang berniat mendirikan sebuah bangunan, dan melalui bangunan tersebut masyarakat wajib untuk membayar retribusi izin mendirikan bangunan yang telah ditetapkan oleh Pemerintah Daerah Kota Gorontalo.

Jumlah keseluruhan bangunan di Kota Gorontalo 30.474 Bangunan, yang telah memiliki Izin Mendirikan Bangunan sebanyak 16.520 sedangkan yang tidak memiliki Izin Mendirikan Bangunan sebanyak 13.954 Bangunan. Melihat banyaknya masyarakat yang belum memiliki Izin Mendirikan Bangunan (IMB) menurut informasi yang diperoleh dari masyarakat layanan pengurusan Izin Mendirikan Bangunan (IMB) sulit untuk diakses oleh masyarakat, kurangnya informasi kepada masyarakat mengenai Izin Mendirikan Bangunan, hal ini tentunya menjadi masalah yang sangat krusial, karena apabila tidak memiliki izin mendirikan bangunan, maka sudah pasti masyarakat tidak membayar retribusi izin mendirikan bangunan, dan tentunya hal ini dapat menurunkan peningkatan asli daerah Kota Gorontalo melalui retribusi IMB.

Selanjutnya berdasarkan hasil observasi di lapangan menunjukkan bahwa tingkat kesadaran masyarakat Kota Gorontalo untuk mengurus izin mendirikan bangunan (IMB) masih sangat rendah, karena \pm 30 ribu bangunan rumah tinggal yang ada di Kota Gorontalo hanya sekitar 50,3\% yang memiliki IMB, dan selebihnya belum memiliki IMB atau berstatus bangunan liar. Tetapi ini hanya berlaku untuk rumah tinggal, sedangkan untuk rumah toko sebagian besar telah memiliki Izin Mendirikan Bangunan (IMB). Dengan demikian, Implementasi Perda Nomor 36 tahun 2011 mengenai IMB ini perlu mendapatkan perhatian khusus oleh Pemerintah Kota Gorontalo, karena jika tidak ditertibkan mulai dari sekarang 
selain menurunkan pendapatan asli daerah Kota Gorontalo hal ini juga akan berdampak pada perkembangan Kota Gorontalo yang tidak terarah dan selanjutnya akan menimbulkan kesulitan dalam penataan kota dimasa mendatang.

Terkait dengan teori diatas peneliti menemukan permasalahan dilapangan dan informasi serta keluhan dari berbagai masyarakat yaitu (1) kurangnya sosialisasi yang dilakukan oleh dinas teknis dalam hal ini Dinas Pekerjaan Umum dan Penataan Ruang serta Badan Penanaman Modal Pelayanan Terpadu Satu Pintu Kota Gorontalo. Akibatnya masyarakat belum memahami arti pentingnya IMB, juga belum memahami standar atau prosedur yang harus dilakukan oleh masyarakat yang ingin melaksanakan pembangunan. Hal ini menjadikan masyarakat cenderung melaksanakan pembangunan terlebih dahulu setelah itu melakukan pengajuan IMB.

Selain itu, (2) kurang efektifnya koordinasi yang dilakukan antar dinas terkait pelaksanaan IMB dalam memberikan pelayanan kepada masyarakat, yang berujung pada lambannya penerbitan Izin Mendirikan Bangunan dan tidak adanya kepastian waktu kapan terbitnya Izin Mendirikan Bangunan (IMB) tersebut. (3) Minimnya sumber daya yang dimiliki oleh Instansi terkait pelayanan IMB baik itu dari Dinas Pekerjaan Umum Dan Penataan Ruaang Kota Gorontalo maupun dari Badan Penanaman Modal Pelayanan Terapadu Satu Pintu. (4) Jika dilihat dari sikap pelaksana yang ada, dinilai kurang profesional dan tidak adil, karena adanya izin yang diberikan kepada pihak-pihak tertentu dalam melakukan pembangunan yang tidak sesuai dengan peruntukannya, karena memiliki kedekatan dengan pejabat tertentu, sehingga menimbulkan kecemburuan sosial bagi masyarakat, tetapi apabila dilihat dari segi aturan, bangunan tersebut ternyata tidak layak mendapatkan IMB, namun pelaksanaan pembangunan tetap dilaksanakan.

\section{B. KAJIAN PUSTAKA}

\section{Izin Mendirikan Bangunan}

Izin mendirikan bangunan adalah perizinan yang diberikan oleh pemerintah kabupaten/kota kepada pemilik gedung untuk membangun baru, mengubah, memperluas, mengurangi dan atau merawat bangunan gedung sesuai dengan persyaratan administrasi dan persyaratan teknis yang berlaku. Marihot Pahala Siahaan, (2008:54)

Izin (verguning), adalah suatu persetujuan dari penguasa berdasarkan Undang-undang atau Peraturan Pemerintah untuk dalam keadaan tertentu menyimpang dari ketentuan-ketentuan larangan peraturan perundang-undangan. Jadi izin itu pada prinsipnya adalah sebagai dispensasi atau pelepasan/ pembebasan dari suatu larangan(Adrian Sutedi, 2010, 168). 
Menurut Susanta (2009: 6), izin mendirikan bangunan (IMB) adalah izin yang diberikan oleh pemerintah daerah kepada pribadi, sekelompok orang atau badan untuk membangun dalam rangka pemanfaatan ruang sesuai dengan izin yang diberikan karena telah memenuhi ketentuan dari berbagai aspek, baik pertanahan, teknis, perencanaan serta lingkungan.

\section{Pelayanan Izin Mendirikan Bangunan}

Salah satu tugas pokok aparatur pemerintah dalam penyelenggaraan pemerintahan adalah memberikan pelayanan kepada masyarakat. Menurut Ridwan (2009:163) ada beberapa hambatan yang biasanya dikeluhkan oleh masyarakat yang ingin mengurus perizinan yaitu:

a. Biaya perizinan

1. Biaya pengurusan izin sangat memberatkan bagi pelaku usaha kecil. Besarnya biaya perizinan seringkali tidak transparan.

2. Penyebab besarnya biaya disebabkan karena pemohon tidak mengetahui besar biaya resmi utuk pengurusan izin.

b. Waktu

1. Waktu yang diperlukan mengurus izin relatif lama karena prosesnya yang berbelitbelit

2. Tidak adanya kejelasan kapan izin diselesaikan.

3. Proses perizinan tergantung pada pola birokrasi setempat

c. Persyaratan

1. Persyaratan yang ditetapkan seringkali sulit untuk diperoleh

2. Persyaratan yang diminta secara berulang-ulang

\section{Penataan Bangunan}

Berdasarkan pada Peraturan Menteri Pekerjaan Umum Nomor 06/PRT/M/2007 Tentang Pedoman Umum Rencana Tata Bangunan dan Lingkungan, Tata Bangunan merupakan produk dari penyelenggaraan bangunan gedung beserta lingkungannya sebagai wujud pemanfaatan ruang, meliputi berbagai aspek termasuk pembentukan citra/karakter fisik lingkungan, besaran, dan konfigurasi dari elemen-elemen blok, kavling/petak lahan, bangunan, serta ketinggian dan elevasi lantai bangunan, yang dapat menciptakan kualitas ruang kota yang akomodatif terhadap keragaman kegiatan yang ada, terutama yang berlangsung dalam ruang-ruang publik.

Penataan bangunan merupakan kegiatan pembangunan untuk merencanakan atau melestarikan bangunan tertentu sesuai dengan prinsip penataan ruang dan pengendalian 
Volume 15 Nomor 2, Desember 2019

Halaman 65-83
Implementasi Peraturan Daerah Nomor 36 Tahun 2011

Tentang izin Mendirikan Bangunan dalam Peningkatan Pendapatan Asli Daerah Kota Gorontalo

bangunan gedung secara optimal, yang terdiri dari proses perencanaan teknis dan pelaksanaan konstruksi, serta kegiatan pemanfaatan, pelestarian dan pembongkaran bangunan gedung. Dalam Peraturan Menteri tersebut menguraikan empat komponen penataan bangunan yaitu: Pertama, pengaturan blok lingkungan yang merupakan perencanaan pembagian lahan dalam kawasan menjadi blok dan jalan, dimana blok terdiri atas kavling/petak lahan dengan konfigurasi tertentu yang terdiri atas: bentuk dan ukuran blok; pengelompokan dan konfigurasi blok; serta ruang terbuka dan tata hijau. Kedua, pengaturan kavling/petak lahan, perencanaan pembagian lahan dalam blok menjadi sejumlah kavling/blok lahan dengan ukuran, bentuk, pengelompokan dan konfigurasi tertentu. Ketiga, pengaturan bangunan yang merupakan perencanaan pengaturan massa bangunan dalam blok/kavling yang terdiri atas : pengelompokan bangunan; letak dan orientasi bangunan; sosok massa bangunan; dan ekspresi arsitektur bangunan.

\section{METODOLOGI PENELITIAN}

Berdasarkan latar belakang serta kerangka konseptual yang telah dikemukakan sebelumnya, maka yang menjadi tempat atau lokasi dalam penelitian ini adalah pada Dinas Pekerjaan Umum dan Penataan Ruang Kota Gorontalo dan Badan Penanaman Modal dan Pelayanan Terpadu Satu Pintu Kota Gorontalo. Teknik analisis data yang digunakan dalam penelitian kualitatif adalah analisis model interaktif (Miles \&Huberman, 1992:15-19), yang terdiri atas Pengumpulan data, Reduksi data, Penyajian data dan Penarikan kesimpulan.

\section{HASIL PENELITIAN}

\section{Rasio Pertumbuhan Retribusi izin mendirikan bangunan (IMB)}

Adapun hasil dari data rasio pertumbuhan retribusi izin mendirikan bangunan (IMB) selama 2014-2016 dapat disajikan tabel 4.2 berikut ini:

Tabel 1: Rasio pertumbuhan retribusi izin mendirikan bangunan (IMB) selama 20142016

\begin{tabular}{|c|c|c|}
\hline No & Tahun & Pertumbuhan \\
\hline 1 & 2014 & $-20,586 \%$ \\
\hline 2 & 2015 & $28,117 \%$ \\
\hline 3 & 2016 & $17,871 \%$ \\
\hline \multicolumn{2}{|c|}{ Rata-Rata } & $\mathbf{8 , 4 6 8 \%}$ \\
\hline
\end{tabular}

Berdasarkan hasil pada tabel di atas ditemukan bahwa pertumbuhan retribusi izin mendirikan bangunan (IMB) selama 2014-2016 cenderung fluktuatif dimana pada tahun 2014 sebesar $-20,586 \%$ yang menunjukan bahwa terjadi penurunan pertumbuhan retribusi izin 
Volume 15 Nomor 2, Desember 2019

Halaman 65-83
Implementasi Peraturan Daerah Nomor 36 Tahun 2011

Tentang lin Mendirikan Bangunan dalam Peningkatan Pendapatan Asli Daerah Kota Gorontalo

mendirikan bangunan (IMB) dari tahun 2013 ke tahun 2014. Kemudian pada tahun 2015 mengalami peningkatan pula sebesar 28,117\%. Terakhir pada tahun 2016 mengalami penurunan sebesar $17,871 \%$. Meskipun fluktuatif namun rata-rata dari pertumbuhannya bernilai positif sebesar $8,468 \%$ yang menunjukan bahwa rata-rata pertumbuhan pertumbuhan retribusi izin mendirikan bangunan (IMB) selama 2014-2016 berada pada daerah rasional atau sebagaimana yang diharapkan oleh pemerintah Kota Gorontalo. Rasio pertumbuhan yang positif menjadi gambaran pula bahwa adanya kemampuan yang baik dari pemerintah dalam meningkatkan sumber-sumber penerimaan daerah.

\section{Rasio Efektivitas Retribusi izin mendirikan bangunan (IMB)}

Rasio efektivitas pajak/retribusi daerah dianggap baik apabila mencapai angka minimal 1 atau 100\%. Dengan menggunakan kriteria penilaian Efektivitas sebagai berikut:

Tabel 2 Interprestasi Nilai Efektivitas

\begin{tabular}{cc}
\hline Presentase $(\%)$ & Kriteria \\
\hline$\geq 100 \%$ & SangatEfektif \\
$90-100 \%$ & Efektif \\
$80-90 \%$ & CukupEfektif \\
$60-80 \%$ & KurangEfektif \\
$\leq 60 \%$ & TidakEfektif \\
\hline
\end{tabular}

Sumber data : Depdagri, Kepmendagri No.690.900.327 (dalam Sari: 2011)

Adapun hasil dari data rasio efektivitas retribusi izin mendirikan bangunan (IMB) selama 2014-2016 dapat disajikan tabel 3 berikut ini:

Tabel 3: Rasio Efektivitas retribusi izin mendirikan bangunan (IMB) selama 2014-2016

\begin{tabular}{|c|c|c|c|}
\hline No & Tahun & Efektivitas & Kriteria \\
\hline 1 & 2014 & $40,383 \%$ & Tidak Efektif \\
\hline 2 & 2015 & $51,738 \%$ & Tidak Efektif \\
\hline 3 & 2016 & $97,575 \%$ & Efektif \\
\hline \multicolumn{2}{|c|}{ Rata-Rata } & $\mathbf{6 3 , 2 3 2 \%}$ & Kurang Efektif \\
\hline
\end{tabular}

Berdasarkan hasil pada tabel di atas ditemukan bahwa efektivitas dari retribusi izin mendirikan bangunan (IMB) memiliki nilai rata-rata sebesar 63,232\% dari anggaran yang ditetapkan oleh pemerintah. Nilai ini jika dikaitkan dengan kriteria dari efektivitas rasio kinerja keuangan daerah (efektivitas) maka terletak pada kriteria yang kurang efektif. Sementara itu dilihat per tahun ditemukan bahwa pada tahun 2014 merupakan periode yang nilai efektivitasnya paling kecil dan masuk dalam kategori yang tidak efektif. Hal tersebut karena pada tahun 2014 penentuan anggaran yang terlampau besar. Kemudian pada tahun 2015 dan 2016 mengalami peningkatan karena berbagai langkah intensifikasi ekstensifikasi 
Volume 15 Nomor 2, Desember 2019

Halaman 65-83
Implementasi Peraturan Daerah Nomor 36 Tahun 2011

Tentang lin Mendirikan Bangunan dalam Peningkatan Pendapatan Asli Daerah Kota Gorontalo

yang dilakukan oleh pemerintah Kota Gorontalo sehingga penerimaanya menjadi lebih besar dari periode sebelumnya.

\section{Rasio Kontribusi Retribusi izin mendirikan bangunan (IMB)}

Adapun hasil dari data rasio kontribusi retribusi izin mendirikan bangunan (IMB) selama 2014-2016 dapat disajikan tabel 4 berikut ini:

Tabel 4: Rasio Kontribusi retribusi izin mendirikan bangunan (IMB) selama 2014-2016

\begin{tabular}{|c|c|c|c|}
\hline \multirow{2}{*}{ No } & \multirow{2}{*}{ Tahun } & \multicolumn{2}{|c|}{ Kontribusi } \\
\hline & & Retribusi & PAD \\
\hline 1 & 2014 & $25,271 \%$ & $1,295 \%$ \\
\hline 2 & 2015 & $16,942 \%$ & $1,450 \%$ \\
\hline 3 & 2016 & $16,061 \%$ & $1,416 \%$ \\
\hline \multicolumn{2}{|c|}{ Rata-Rata } & $19,425 \%$ & $1,387 \%$ \\
\hline
\end{tabular}

Berdasarkan hasil pada tabel di atas ditemukan bahwa rasio kontribusi dari retribusi izin mendirikan bangunan (IMB) terhadap jumlah retribusi masih sangat minim, yakni hanya sebesar 19,425\%. Nilai kontribusi retribusi izin mendirikan bangunan (IMB) terhadap retribusi yang tertinggi yakni pada tahun 2014 sementara yang terendah yakni pada tahun 2016. Dengan menggunakan persentase dan kriteria sebagai ukurannya, dapat diketahui apabila 0\%-19\% maka termasuk ke dalam kategori kecil. Dimana jika dikaitkan dengan ketentuan kriteria rasio kontribusi maka nilai tersebut menggambarkan bahwa kontribusi retribusi izin mendirikan bangunan (IMB) masih sangat kecil.

Kemudian untuk rasio kontribusi retribusi izin mendirikan bangunan (IMB) terhadap pendapatan asli daerah yakni memiliki rata-rata sebesar $1,010 \%$, yang menunjukan bahwa kemampuan retribusi izin mendirikan bangunan (IMB) dalam meningkatkan pendapatan asli daerah masih sangat minim dana masih perlu mendapat perhatian dari pemerintah Kota Gorontalo (Dinas Penanaman Modal dan Pelayanan Terpadu Satu Atap (DPM-PTSP) Kota Gorontalo). Meskipun komposisi dari retribusi izin mendirikan bangunan (IMB) menjadi salah satu retribusi yang besar dan memiliki tingkat efektivitas yang cukup tinggi namun dari rasio kontrbusi dapat diketahui bahwa proporsi dari retribusi izin mendirikan bangunan (IMB) selama 3 tahun terakhir mengalami penurunan atau dengan kata lain peningkatan nominal tidak diikuti dengan peningkatan proporsi dalam total retribusi maupun dari aspke pendapatan asli daerah Kota Gorontalo secara keseluruhan.

\section{Strategi Implementasi Perda Nomor 36 Tahun 2011 Tentang Izin Mendirikan} Bangunan Dalam Peningkatan Pendapatan Asli Daerah Kota Gorontalo

Berdasarkan hasil wawancara yang kemudian dikolaborasikan dengan observasi yang dilakukan peneliti maka berikut ini disajikan temuan penelitian mengenai Strategi 
Volume 15 Nomor 2, Desember 2019

Halaman 65-83
Implementasi Peraturan Daerah Nomor 36 Tahun 2011 Tentang izin Mendirikan Bangunan dalam Peningkatan Pendapatan Asli Daerah Kota Gorontalo

Implementasi Perda Nomor 36 Tahun 2011 Tentang Izin Mendirikan Bangunan Dalam Peningkatan Pendapatan Asli Daerah Kota Gorontalo:

Tabel 5: Temuan Penelitian Mengenai Strategi Implementasi Perda Nomor 36 Tahun 2011 Tentang Izin Mendirikan Bangunan Dalam Peningkatan Pendapatan Asli Daerah Kota Gorontalo

\begin{tabular}{|c|c|c|c|c|c|}
\hline \multirow{3}{*}{ NO } & \multirow{3}{*}{$\begin{array}{c}\text { Aspek } \\
\text { Penilaian }\end{array}$} & \multicolumn{4}{|c|}{ Temuan Penelitian } \\
\hline & & \multicolumn{2}{|c|}{ Plus } & \multicolumn{2}{|r|}{ Minus } \\
\hline & & Temuan & Dampak & Temuan & Dampak \\
\hline \multirow{2}{*}{1} & \multirow{2}{*}{ Pelayanan } & $\begin{array}{l}\text { Pelayanan yang dilakukan } \\
\text { terpadu }\end{array}$ & $\begin{array}{l}\text { Pelayanan lebih } \\
\text { terarah }\end{array}$ & $\begin{array}{l}\text { Prosedur pelayanan yang } \\
\text { rumit }\end{array}$ & $\begin{array}{l}\text { Keengganan dalam memenuhi } \\
\text { kewajiban }\end{array}$ \\
\hline & & & & $\begin{array}{l}\text { Aspek tangible kurang } \\
\text { terpenuhi }\end{array}$ & $\begin{array}{l}\text { Pelayanan menjadi kurang } \\
\text { maksimal }\end{array}$ \\
\hline 2 & Pemungutan Retribusi & $\begin{array}{l}\text { Pendataan kembali } \\
\text { bangunan tanpa IMB }\end{array}$ & $\begin{array}{l}\text { Objek retribusi } \\
\text { menjadi lebih jelas }\end{array}$ & $\begin{array}{l}\text { Tindak lanjut pendataan } \\
\text { kurang maksimal }\end{array}$ & Target menjadi kurang terpenuhi \\
\hline \multirow{2}{*}{3} & \multirow{2}{*}{ Pengawasan } & $\begin{array}{l}\text { Pengawasan internal yang } \\
\text { aktif }\end{array}$ & $\begin{array}{l}\text { Penerapan kebijakan } \\
\text { menjadi lebih optimal }\end{array}$ & $\begin{array}{l}\text { Pengawasan hanya pada } \\
\text { aspek teknis }\end{array}$ & $\begin{array}{l}\text { Dalam hal pelayanan kurang } \\
\text { mendapatkan perhatian }\end{array}$ \\
\hline & & Pengawasan ekternal & $\begin{array}{l}\text { Penerapan kebijakan } \\
\text { menjadi lebih optimal }\end{array}$ & & \\
\hline 4 & Sanksi & & & Sanksi yang kurang tegas & $\begin{array}{l}\text { Tidak adanya efek jerah bagi } \\
\text { masyarakat }\end{array}$ \\
\hline
\end{tabular}

Berdasarkan hasil dari tabel 5 di atas maka dapat dijabarkan hasil dari wawancara yang dikolaborasikan dengan observasi bahwa Layanan IMB memiliki tingkat penyelesaian yang lebih rumit, karena menyangkut layak/tidak layaknya struktur bangunan yang akan ditempati. Dokumen IMB memiliki kekuatan hukum bagi masyarakat sekaligus merupakan bentuk perlindungan hukum terhadap masyarakat pemilik bangunan dalam jangka waktu panjang terhadap masalah hukum yang dihadapi dikemudian hari nanti. Oleh karena itu diperlukan ketilitian yang tinggi dalam merekomendasikan dokumen perizinan dimaksud. Layanan IMB memerlukan intervensi pemerintah. Oleh karena itu dalam pengurusannya membutuhkan syarat administrasi dan mekanisme prosedur yang cukup rumit pula. Karena tingkat kesulitan dalam proses yang cukup tinggi, maka biaya administrasinyapun lebih mahal, yaitu sesuai dengan luas bangunan yang dimiliki dan lokasi bangunan yang strategis (sesuai NJOP).

Berdasarkan tabel dan grafik di atas dapat pula diketahui bahwa pemungutan tarif retribusi didasarkan pada tarif yang ada pada bab IV pasal 8 Perda Nomor 36 Tahun 2011 Tentang Izin Mendirikan Bangunan dimana penentuan retribusi didasarkan pada volume atau luas bangunan kemudian dikali dengan indeks bangunan serta tarif retribusi yang telah ditetapkan dalam aturan tersebut. Kemudian strategi yang dilakukan dalam pelayanan yakni dengan menerapkan sanksi yang jelas bagi masyarakat yang tidak patuh dimana hal tersebut sebagaimana tertuang dalam bab XI pasal 16 Perda Nomor 36 Tahun 2011 Tentang Izin Mendirikan Bangunan bahwa sanksi diberikan sebesar 2\% tiap bulan selama kewajiban retribusi dari wajib retribusi tersebut masih dalam tahap tidka bayar atau kurang bayar. 
Volume 15 Nomor 2, Desember 2019

Halaman 65-83
Implementasi Peraturan Daerah Nomor 36 Tahun 2011

Tentang izin Mendirikan Bangunan dalam Peningkatan Pendapatan Asli Daerah Kota Gorontalo

Sehingga secara keseluruhan Implementasi Perda Nomor 36 Tahun 2011 Tentang Izin Mendirikan Bangunan Dalam Peningkatan Pendapatan Asli Daerah Kota Gorontalo sudah baik namun masih perlu adanya pembenahan terutama pada pelayanan yang kurang optimal dan dapat menimbulkan penurunan kepatuhan masyarakat, serta pada sanksi yang diberikan masih harus diperhatian terutama dalam aspek ketegasan dalam sanksi sehingga dapat menimbulkan efek jerah. Sementara itu strategi yang dapat dilakukan dalam Implementasi Perda Nomor 36 Tahun 2011 Tentang Izin Mendirikan Bangunan Dalam Peningkatan Pendapatan Asli Daerah Kota Gorontalo yakni strategi stabil jika keempat aspek tersebut ternyata berdampak pada kepatuhan wajib retribusi IMB dan strategi diversifikasi jika ternyata keempat aspek tersebut belum begitu optimal.

Faktor-faktor yang menentukan keberhasilan Implementasi Perda Nomor 36 Tahun 2011 Tentang Izin Mendirikan Bangunan Dalam Peningkatan Pendapatan Asli Daerah Kota Gorontalo

Berdasarkan hasil wawancara maka berikut ini disajikan temuan penelitian terkait dengan Faktor-faktor yang menentukan keberhasilan Implementasi Perda Nomor 36 Tahun 2011 Tentang Izin Mendirikan Bangunan Dalam Peningkatan Pendapatan Asli Daerah Kota Gorontalo:

Tabel 6: Temuan Penelitian Mengenai Faktor-faktor yang menentukan keberhasilan Implementasi Perda Nomor 36 Tahun 2011 Tentang Izin Mendirikan Bangunan Dalam Peningkatan Pendapatan Asli Daerah Kota Gorontalo

\begin{tabular}{|c|c|c|c|c|c|}
\hline \multirow{3}{*}{ NO } & \multirow{3}{*}{$\begin{array}{c}\text { Aspek } \\
\text { Penilaian }\end{array}$} & \multicolumn{4}{|c|}{ Temuan Penelitian } \\
\hline & & \multicolumn{2}{|c|}{ Plus } & \multicolumn{2}{|c|}{ Minus } \\
\hline & & Temuan & Dampak & Temuan & Dampak \\
\hline 1 & Komunikasi & Koordinasi antar dinas terkait & $\begin{array}{l}\text { Pengurusan sedikit lebih } \\
\text { mudah }\end{array}$ & $\begin{array}{l}\text { Sosialisasi belum } \\
\text { maksimal }\end{array}$ & $\begin{array}{l}\text { Masyarakat menjadi kurang } \\
\text { paham }\end{array}$ \\
\hline \multirow{3}{*}{2} & \multirow{3}{*}{$\begin{array}{l}\text { Resources (Sumber } \\
\text { Daya) }\end{array}$} & $\begin{array}{l}\text { Pegawai pelayanan sudah } \\
\text { optimal }\end{array}$ & $\begin{array}{l}\text { Pelayanan menjadi } \\
\text { lebuh baik }\end{array}$ & $\begin{array}{l}\text { Pegawai teknis yang } \\
\text { belum maksimal }\end{array}$ & $\begin{array}{l}\text { Waktu peninjauan lebih } \\
\text { lama }\end{array}$ \\
\hline & & & & $\begin{array}{l}\text { Sarana dan prasarana } \\
\text { masih sangat kurang }\end{array}$ & Hasil kerja kurang maksimal \\
\hline & & & & $\begin{array}{l}\text { Kerusakan pada sarana } \\
\text { dan prasarana }\end{array}$ & Hasil kerja kurang maksimal \\
\hline 3 & $\begin{array}{l}\text { Dispotitions or attitudes } \\
\text { (Sikap Pelaksana ) }\end{array}$ & $\begin{array}{l}\text { Dukungan pelaksana yang } \\
\text { baik }\end{array}$ & $\begin{array}{l}\text { Pekerjaan bisa lebih } \\
\text { baik }\end{array}$ & & \\
\hline 4 & $\begin{array}{l}\text { Bureaucratic Structure } \\
\text { (Struktur Birokrasi) }\end{array}$ & Telah memiliki SOP dan SPM & $\begin{array}{l}\text { Ada pedoman yang } \\
\text { diikuti dalam kebijakan } \\
\text { retribusi IMB }\end{array}$ & $\begin{array}{l}\text { SOP masih kurang } \\
\text { dipahami }\end{array}$ & $\begin{array}{l}\text { Banyak pekerjaan tidak } \\
\text { sesuai SOP }\end{array}$ \\
\hline
\end{tabular}

Berdasarkan hasil dan gambar di atas maka dapat dijabarkan hasil dari wawancara yang dikolaborasikan dengan observasi ditemukan bahwa

1) Komunikasi 
Pada aspek komunikasi dditemukan bahwa sosialisasi masih sangat jarang dilakukan dan jika dilakukan hanya pada tingkat kelurahan sehingga informasi mengenai pentingnya IMB masih belum optimal yang akibatnya banyak masyarakat yang masih kurang paham mengenai kewajibannya sebagai wajib retribusi.

\section{2) Sumber Daya}

Temuan penelitian dari wawancara dan observasi mengenai sumber daya dapat dilihat dari 2 aspek yakni sarana prasarana dan sumber daya manusia. Sarana dan prasarana masih sangat minim terutama dalam pelayanan teknis, sehingga ketika melakukan pelayanan teknis maka petugas yang bertindak dalam pelayanan teknis tersebut akan saling menunggu penggunaan sarana dan prasarana dari petugas lainnya. Kemudian sarana dan prasarana yang cenderung kurang baik lagi digunakan. Jumlah pegawai teknis yang sedikit sehingga membuat banyak pekerjaan yang berhubungan dengan hal-hal teknis dilakukan atau dikerjakan secara tepat waktu. Sehingga dalam hal ini maka perlunya penambahan jumlah pegawai yang bertugas dalam hal-hal teknis karena pentingnya hal teknis yang bukan hanya bertugas untuk turun lapangan, namun juga bertugas dalam memberikan arahan atau masukan bagi masyarakat yang hendak mendirikan bangunan.

3) Sikap pelaksana

Sikap pelaksana merupakan salah satu aspek yang krusial karena dengan dukungan pelaksana serta dengan komitmen yang tinggi akan membuat sebuah pelayanan dirasakan sangat puas. Hasil penelitian melalui wawancara dan observasi ditemukan bahwa sikap pelaksana sudah menunjukan sikap yang baik namun komitmen dengan waktu masih perlu untuk dibenahi terutama oleh pelaksana teknis serta bagi pegawai administrasi masih perlu untuk meningkatkan sikap empati dalam memberikan pelayanan.

4) Struktur Organisasi

Penerbitan IMB menyangkut keselamatan penduduk atas bangunan yang dihuni, maka dibutuhkan peninjauan langsung ke lapangan untuk memastikan struktur yang memenuhi standar dan lokasi yang tidak mengganggu kepentingan umum. Pelayanan IMB membutuhkan fasilitas pendukung yang lebih spesifik dibandingkan dengan layanan perizinan yang lainnya. Dengan tingkat kerumitan penerbitan dokumen izin baik layanan administrasi maupun peninjauan di lapangan, maka dibutuhkan pula SDM yang memiliki pengetahuan spesifik tentang bangunan. 


\section{Upaya Optimalisasi Implementasi Perda Nomor 36 tahun 2011 dalam Peningkatan Pendapatan Asli Daerah}

Pemecahan masalah adalah suatu proses terencana yang perlu dilaksanakan agar memperoleh penyelesaian tertentu dari sebuah masalah yang mungkin tidak didapat dengan segera. Sehingga berdasarkan hasil wawancara yang kemudian dikolaborasikan dengan observasi yang dilakukan peneliti maka berikut ini disajikan temuan penelitian terkait dengan Upaya Optimalisasi Implementasi Perda Nomor 36 tahun 2011 dalam Peningkatan Pendapatan Asli Daerah:

Tabel 7: Temuan Penelitian Mengenai Upaya Optimalisasi Implementasi Perda Nomor 36 tahun 2011 dalam Peningkatan Pendapatan Asli Daerah

\begin{tabular}{|c|c|c|c|}
\hline \multirow{2}{*}{ NO } & \multirow{2}{*}{$\begin{array}{c}\text { Aspek } \\
\text { Penilaian }\end{array}$} & \multicolumn{2}{|r|}{ Temuan Penelitian } \\
\hline & & Temuan & Dampak \\
\hline \multirow{4}{*}{1} & \multirow{4}{*}{ Intensifikasi } & Evaluasi kebijakan & Sebagai bentuk optimalisasi pada tahap perencanaan \\
\hline & & $\begin{array}{l}\text { Tindak lanjut rekomendasi } \\
\text { pengawasan }\end{array}$ & Hasil pekerjaan akan lebih baik \\
\hline & & $\begin{array}{l}\text { Memperhatikan angka ideal dalam } \\
\text { anggaran }\end{array}$ & $\begin{array}{l}\text { Target akan mudah dicapai dimana pencapaian target } \\
\text { merupakan ukuran keberhasilan }\end{array}$ \\
\hline & & Bimbingan teknis dan pelatihan & $\begin{array}{l}\text { Pegawai akan memiliki pengetahuan dan komitmen yang } \\
\text { tinggi }\end{array}$ \\
\hline \multirow{3}{*}{2} & \multirow{3}{*}{ Ekstensifikasi } & $\begin{array}{l}\text { Integrasi IMB dengan perizinan } \\
\text { lainnya }\end{array}$ & $\begin{array}{l}\text { Masyarakat akan susah dalam mengurus surat-surat atau } \\
\text { izizn lain sehingga harus lebih dulu mengurus IMB }\end{array}$ \\
\hline & & Sosialisasi dengan cara yang efisien & Pengetahuan masyarakat dan kesadaran akan meningkat \\
\hline & & $\begin{array}{l}\text { Pendataan kembali wajib retribusi } \\
\text { yang memiliki banguna tanpa IMB }\end{array}$ & $\begin{array}{l}\text { Dengan pendataan maka akan lebih banyak wajib retribusi } \\
\text { yang dapat dirangkul }\end{array}$ \\
\hline
\end{tabular}

Berdasarkan hasil dari tabel di atas maka dapat dijabarkan hasil dari wawancara yang dikolaborasikan dengan observasi ditemukan bahwa untuk intensifikasi dapat dilakukan dengan Evaluasi kebijakan, Tindak lanjut rekomendasi pengawasan, Memperhatikan angka ideal dalam anggaran dan Bimbingan teknis dan pelatihan. Dengan tindakan ini maka diharapkan akan bermanfaat atau berdampak baik dimana Sebagai bentuk optimalisasi pada tahap perencanaan, hasil pekerjaan akan lebih baik, target akan mudah dicapai dimana pencapaian target merupakan ukuran keberhasilan serta pegawai akan memiliki pengetahuan dan komitmen yang tinggi. Kemudian melakukan tindakan ekstensifikasi berupa Integrasi IMB dengan perizinan lainnya, Sosialisasi dengan cara yang efisien dan Pendataan kembali wajib retribusi yang memiliki banguna tanpa IMB, sehingga akan berdampak pada masyarakat akan susah dalam mengurus surat-surat atau izizn lain sehingga harus lebih dulu mengurus IMB, Pengetahuan masyarakat dan kesadaran akan meningkat serta dengan pendataan maka akan lebih banyak wajib retribusi yang dapat dirangkul 


\section{E. PEMBAHASAN}

\section{Strategi Implementasi Perda Nomor 36 Tahun 2011 Tentang Izin Mendirikan Bangunan Dalam Peningkatan Pendapatan Asli Daerah Kota Gorontalo}

Secara keseluruhan Implementasi Perda Nomor 36 Tahun 2011 Tentang Izin

Mendirikan Bangunan Dalam Peningkatan Pendapatan Asli Daerah Kota Gorontalo sudah baik namun masih perlu adanya pembenahan terutama pada pelayanan yang kurang optimal dan dapat menimbulkan penurunan kepatuhan masyarakat, serta pada sanksi yang diberikan masih harus diperhatian terutama dalam aspek ketegasan dalam sanksi sehingga dapat menimbilkan efek jerah. Sementara itu strategi yang dapat dilakukan dalam Implementasi Perda Nomor 36 Tahun 2011 Tentang Izin Mendirikan Bangunan Dalam Peningkatan Pendapatan Asli Daerah Kota Gorontalo yakni strategi stabil jika keempat aspek tersebut ternyata berdampak pada kepatuhan wajib retribusi IMB dan strategi diversifikasi jika ternyata keempat aspek tersebut belum begitu optimal. Strategi yang harus mendapat perhatian karena strateginya kurang baik yakni pada sanksi yang diberikan belum begitu memberikan efek jera bagi masyarakat yang kurang patuh dalam hal retribusi daerah

Aspek layanan masih harus terus ditingkatkan agar ada kemauan masyarakat dalam memenuhi kewajibannya. Hal tersebut sebagaimana dikatakan oleh Tjiptono dan Diana dalam Syamsi (2008: 26) bahwa kualitas dan kepuasan masyarakat berkaitan erat. Kualitas memberikan suatu dorongan kepada masyarakat untuk menjalin ikatan yang kuat kepada perusahaan. Dalam jangka panjang ikatan seperti ini memungkinkan perusahaan untuk memahami dengan seksama harapan masyarakat serta kebutuhan mereka. Dengan demikian, perusahaan dapat meningkatkan kepuasan masyarakat dimana perusahaan memaksimumkan pengalaman masyarakat yang menyenangkan dan meminimumkan atau meniadakan pengalaman masyarakat yang kurang menyenangkan. Pada gilirannya kepuasan masyarakat dapat menciptakan kesetiaan atau loyalitas masyarakat kepada perusahaan yang memberikan kualitas memuaskan

Hal yang sama juga diungkapkan oleh McCann.,et.,al (2014) bahwa kinerja yang optimal dari pegawai akan memberikan dampak yang baik bagi persepsi masyarakat. Penilaian kinerja aparatur adalah proses penilaian hasil kerja yang akan digunakan oleh pihak manajemen untuk memberikan informasi kepada para aparatur secara individual, tentang mutu hasil pekerjaannya dipandang dari sudut kepentingan perusahaaan. Hal ini dilakukan dengan alasan bahwa pegawai memiliki kemampuan untuk mempengaruhi persepsi pengguna jasa, pegawai merupakan bagian dari jasa itu sendiri, sehingga bagi 
pengguna jasa, pegawai berfungsi sebagai komunikator sekaligus wakil dari citra dari suatu organisasi.

Sementara itu, sanksi juga menjadi aspek yang sangat penting dalam strategi implementasi Perda Nomor 36 tahun 2011 dalam Peningkatan Pendapatan Asli Daerah. Hal tersebut sebagaimana dikatakan oleh Devano dan Rahayu, (2006: 198) bahwa sanksi perpajakan/retribusi terdiri dari sanksi administrasi dan sanksi pidana, sanksi administrasi dapat dijatuhkan apabila wajib pajak/retribusi melakukan pelaggaran terutama atas kewajiban yang ditentukan dalam UU KUP dapat berupa sanksi administrasi bunga, denda dan kenaikan biaya yang harus dibayar. sedangkan sanksi pidana bisa berupa hukuman kurungan dan hukuman penjara.

Dalam undang-undang perpajakan/retribusi terdapat dua jenis sanksi, berupa sanksi pidana dan administrasi. Sanksi perpajak/retribusian dikenakan kepada wajib pajak/retribusi yang tidak patuh dalam memenuhi perpajak/retribusiannya. Sanksi yang semakin berat tentunya akan berdampak pada kepatuhan wajib pajak/retribusi. Sebagaimana diungkapkan oleh Rohmawati dan Rasmini (2013) bahwa Sanksi perpajak/retribusian berpengaruh positif pada kepatuhan wajib pajak/retribusi.

Sedangkan aspek yang sudah baik namun masih harus lebih ditingkatkan yakni pengawasan karena pengawasan akan membawa peran penting baik bagi pelayanan administrasi dan teknis dalam IMB. Hal tersebut sebagaimana dikatakan oleh Toding (2016: 386) bahwa salah satu fungsi dari manajemen sumber daya manusia adalah pengawasan. Pengawasan adalah proses pengamatan pelaksanaan seluruh kegiatan organisasi untuk menjamin agar semua pekerjan yang sedang dilakukan berjalan sesuai dengan rencana yang telah ditentukan sebelumnnya. Pentingnya pengawasan diharapkan dapat memotivasi kinerja pegawai agar pegawai dapat menyelesaikan pekerjaan dengan lebih baik, selain itu pengawasan juga dapat dilakukan untuk membimbing pegawai dalam menyelesaikan pekerjaannya sehingga terhindar dari kesalahan-kesalahan yang tidak diharapkan dan dapat meningkatkan kinerja pegawai itu sendiri.

Pengawasan adalah kegiatan yang membandingkan atau mengukur apa yang sedang atau sudah dilaksanakan dengan kriteria norma standar atau rencana-rencana yang ditetapkan (Handoko dalam Ardansyah dan Wasilawati, 2014: 154). Pengawasan yang dilakukan oleh atasan merupakan pengawasan yang menyeluruh terhadap pelaksanaan kegiatan oleh bawahan dengan maksud agar atasan mengetahui kegiatan nyata dan setiap aspek pelaksanaan tugas atau lingkungan unit organisasi masing-masing dan tidak menyimpang dan 
upaya pencapaian tujuan serta sasaran yang telah ditetapkan. Bila terjadi penyimpangan atasan segera mengambil langkah-langkah perbaikan seperlunya

\section{Faktor-faktor yang menentukan keberhasilan Implementasi Perda Nomor 36 Tahun 2011 Tentang Izin Mendirikan Bangunan Dalam Peningkatan Pendapatan Asli Daerah Kota Gorontalo}

Peraturan Daerah adalah Peraturan Perundang-undangan yang dibentuk oleh Dewan Perwakilan Rakyat Daerah dengan persetujuan bersama Kepala Daerah (Gubernur atau Bupati/Walikota). Peraturan Daerah terdiri atas: Peraturan Daerah Provinsi dan Peraturan Daerah Kabupaten/Kota. Peraturan daerah dibuat untuk mempertegas segala aktivitas dalam hal yang diatur oleh undang-undang. Dimana pada undang-undabg nomor 28 tahun 2009 tentang pajak dan retribusi kemudian oleh pemerintah Kota Gorontalo dikuatkan dengan Perda Nomor 36 Tahun 2011 Tentang Izin Mendirikan Bangunan agar kebijakan ini lebih baik dan berhasil.

Sebagaimana hasil penelitian ditemukan bahwa Faktor-faktor yang menentukan keberhasilan Implementasi Perda Nomor 36 Tahun 2011 Tentang Izin Mendirikan Bangunan Dalam Peningkatan Pendapatan Asli Daerah Kota Gorontalo terdiri dari faktor Komunikasi, Sumber Daya, Disposisi atau Sikap Pelaksana dan Struktur Birokrasi. Dimana hasilnya dapat dijabarkan sebagai berikut ini:

a. Komunikasi

Pada aspek komunikasi dditemukan bahwa sosialisasi masih sangat jarang dilakukan dan jika dilakukan hanya pada tingkat kelurahan sehingga informasi mengenai pentingnya IMB masih belum optimal. Sosialisasi menjadi aspek yang sangat penting dalam keberhasilan karena banyak masyarakat yang masih kurang paham mengenai kewajibannya sebagai wajib retribusi. Pentingnya sosialisasi sebagaimana dikatakan oleh Warouw dkk (2015) bahwa sosialisasi perpajakan diharapkan dapat meningkatkan kepatuhan wajib pajak sehingga jumlah penerimaan pajak dapat bertambah sesuai target. Peningkatan kepatuhan wajib pajak dapat dilihat dari bertambahnya jumlah wajib pajak yang membayar, melapor, dan meyampaikan SPT, serta berkurangnya wajib pajak yang mempunyai tunggakan dan mempunyai sanksi baik administrasi maupun pidana.

b. Sumber Daya

Sumber aday terdiri dari bagaimana sarana dan prasarana di lapangan maupun dalam pelayanan administrasi. Berdasarkan hasil penelitian ditemukan bahwa sarana dan prasarana masih sangat minim terutama dalam pelayanan teknis, sehingga ketika melakukan pelayanan teknis maka petugas yang bertindak dalam pelayanan teknis tersebut akan saling menunggu 
penggunaan sarana dan prasarana dari petugas lainnya. Kemudian sarana dan prasarana yang cenderung kurang baik lagi digunakan. Tidak hanya itu, jumlah pegawai teknis yang sedikit sehingga membuat banyak pekerjaan yang berhubungan dengan hal-hal teknis dilakukan atau dikerjakan secara tepat waktu.

c. Sikap pelaksana

Sikap pelaksana merupakan salah satu aspek yang krusial karena dengan dukungan pelaksana serta dengan komitmen yang tinggi akan membuat sebuah pelayanan dirasakan sangat puas. Hasil penelitian melalui wawancara dan observasi ditemukan bahwa sikap pelaksana sudah menunjukan sikap yang baik namun komitmen dengan waktu masih perlu untuk dibenahi terutama oleh pelaksana teknis serta bagi pegawai administrasi masih perlu untuk meningkatkan sikap empati dalam memberikan pelayanan.

\section{d. Struktur Organisasi}

Penerbitan IMB menyangkut keselamatan penduduk atas bangunan yang dihuni, maka dibutuhkan peninjauan langsung ke lapangan untuk memastikan struktur yang memenuhi standar dan lokasi yang tidak mengganggu kepentingan umum. Pelayanan IMB membutuhkan fasilitas pendukung yang lebih spesifik dibandingkan dengan layanan perizinan yang lainnya. Dengan tingkat kerumitan penerbitan dokumen izin baik layanan administrasi maupun peninjauan di lapangan, maka dibutuhkan pula SDM yang memiliki pengetahuan spesifik tentang bangunan.

Faktor-faktor yang menentukan keberhasilan Implementasi Perda Nomor 36 Tahun 2011 Tentang Izin Mendirikan Bangunan Dalam Peningkatan Pendapatan Asli Daerah Kota Gorontalo terdiri dari faktor Komunikasi, Sumber Daya, Disposisi atau Sikap Pelaksana dan Struktur Birokrasi. Dimana untuk komunikasi ditemukan bahwa sosialisasi masih sangat jarang dilakukan dan jika dilakukan hanya pada tingkat kelurahan, sumber daya masih sangat minim dari kualitas dan kuantitas pegawai serta sarana prasarana, dari aspek sikap pelaksana yang sudah baik dalam komitmen bekerja serta struktur birokrasi yang baik karena adanya ketersediaan SOP dan SPM dalam Implementasi Perda Nomor 36 Tahun 2011 Tentang Izin Mendirikan Bangunan. Faktor yang paling dominan yakni faktor kuantitas pegawai serta sarana prasarana

Sementara yang tidak kalah penting yakni pada aspek internal pemerintahan yakni kemampuan atau kompetensi SDM dan sarana prasarana. Hal tersebut sebagaimana dikatakan oleh Steers (1984) (dalam Sutrisno: 2009 :151) bahwa salah satu faktor yang mempengaruhi prestasi kerja yakni kemampuan dari pegawai itu sendiri. Dengan demikian dapat dikatakan bahwa Sumber daya manusia memegang peran utama dalam setiap kegiatan perusahaan. 
Banyaknya sarana dan prasarana serta sumber daya, tanpa dukungan sumber daya manusia yang handal, kegiatan perusahaan tidak akan berjalan dengan baik.

\section{Upaya Optimalisasi Implementasi Perda Nomor 36 tahun 2011 dalam Peningkatan Pendapatan Asli Daerah}

Pemecahan masalah adalah sebuah proses dimana suatu situasi diamati kemudian bila ditemukan masalah dibuat penyelesaiannya dengan cara menentukan masalah, mengurangi atau menghilangkan masalah atau mencegah masalah itu terjadi. Sebuah kebijakan tentunya tidak selalu berjalan dengan baik, terdapat berbagai masalah. Hal yang sma juga tentunya terjadi pada Implementasi Perda Nomor 36 tahun 2011 dalam Peningkatan Pendapatan Asli Daerah

Upaya Optimalisasi Implementasi Perda Nomor 36 tahun 2011 dalam Peningkatan Pendapatan Asli Daerah dapat dilakukan dengan dua cara yakni dengan intensifikasi dan ekstensifikasi. Untuk intensifikasi dapat dilakukan dengan Evaluasi kebijakan, Tindak lanjut rekomendasi pengawasan, Memperhatikan angka ideal dalam anggaran dan Bimbingan teknis dan pelatihan. Dengan tindakan ini maka diharapkan akan bermanfaat atau berdampak baik dimana Sebagai bentuk optimalisasi pada tahap perencanaan, hasil pekerjaan akan lebih baik, target akan mudah dicapai dimana pencapaian target merupakan ukuran keberhasilan serta pegawai akan memiliki pengetahuan dan komitmen yang tinggi.

Kemudian perlunya dalam melakukan tindakan ekstensifikasi berupa Integrasi IMB dengan perizinan lainnya, Sosialisasi dengan cara yang efisien dan Pendataan kembali wajib retribusi yang memiliki banguna tanpa IMB, sehingga akan berdampak pada masyarakat akan susah dalam mengurus surat-surat atau izin lain sehingga harus lebih dulu mengurus IMB, Pengetahuan masyarakat dan kesadaran akan meningkat serta dengan pendataan maka akan lebih banyak wajib retribusi yang dapat dirangkul

Dalam jangka pendek kegiatan yang paling mudah dan dapat dilakukan adalah melakukan intensifikasi terhadap objek atau sumber pendapatan daerah yang sudah ada, seperti melakukan intensifikasi terhadap pajak daerah dan retribusi daerah. Dengan melakukan efektivitas dan efesiensi sumber atau objek pandapatan daerah, maka akan meningktakan produktivitas PAD tanpa harus melakukan perluasan sumber atau objek pendapatan daerah yang baru yang memerlukanstudi, proses danwaktu yang panjang.

Penelitian ini sejalan dengan pernyataan dari Halim (2001: 147) "ekstensifikasi pajak dan retribusi daerah merupakan kegiatan dalam pungutan pajak daerah dan retribusi daerah dapat diartikan sebagai rangkaian kegiatan ekspansi untuk menambah objek-objek maupun subjek-subjek pajak daerah atau retribusi daerah yang baru, serta berpotensi untuk dipungut 
pajak dan retruibusinya. Sehingga, dengan bertambahnya objek dan subjek retribusi daerah yang baru, diharapkan dapat meningkatkan PAD akibat bertambahnya penerimaan dari objek retribusi daerah baru, hasil dari usaha ekstensifikasi.

Pemerintah di tingkat (SKPD) mengadakan kerjasama dengan pihak kelurahan dan kecamatan untuk melakukan sosialisasi terhadap masyarakat akan pentingnya IMB, sehingga dengan banyaknya masyarakat yang mengajukan IMB maka semakin banyak pula pendapatan daerah yang berasal dari retribusi IMB. Kemudian pemecahan masalah harus segera diimplementasikan kemudian peningkatan pemastian mutu dengan cara menambahkan Tim Pengawas dan Pengendalian di lapangan, sehingga adanya pengawasan pembangunan yang bangunannya sesuai di berkas permohonan baik luas bangunan dan fungsinya.

\section{F. SIMPULAN}

Berdasarkan hasil penelitian dan pembahasan pada bab sebelumnya, maka dapat ditarik beberapa simpulan sebagai berikut:

1. Strategi yang dilakukan dalam Implementasi Perda Nomor 36 Tahun 2011 Tentang Izin Mendirikan Bangunan Dalam Peningkatan Pendapatan Asli Daerah Kota Gorontalo yakni strategi stabil yang digunakan jika pelayanan, pemungutan retribusi, pengawasan dan sanksi berdampak pada kepatuhan wajib retribusi IMB dan menerapkan strategi diversifikasi jika ternyata pelayanan, pemungutan retribusi, pengawasan dan sanksi belum begitu optimal. Strategi yang harus mendapat perhatian karena strateginya kurang baik yakni pada sanksi yang diberikan belum begitu memberikan efek jera bagi masyarakat yang kurang patuh dalam hal retribusi daerah.

2. Faktor-faktor yang menentukan keberhasilan Implementasi Perda Nomor 36 Tahun 2011 Tentang Izin Mendirikan Bangunan Dalam Peningkatan Pendapatan Asli Daerah Kota Gorontalo terdiri dari faktor Komunikasi, Sumber Daya, Disposisi atau Sikap Pelaksana dan Struktur Birokrasi. Dimana untuk komunikasi ditemukan bahwa sosialisasi masih sangat jarang dilakukan dan jika dilakukan hanya pada tingkat kelurahan, sumber daya masih sangat minim dari kualitas dan kuantitas pegawai serta sarana prasarana, dari aspek sikap pelaksana yang sudah baik dalam komitmen bekerja serta struktur birokrasi yang baik karena adanya ketersediaan SOP dan SPM dalam Implementasi Perda Nomor 36 Tahun 2011 Tentang Izin Mendirikan Bangunan. Faktor yang paling dominan yakni faktor kuantitas pegawai serta sarana prasarana

3. Upaya optimalisasi dalam Implementasi Perda Nomor 36 tahun 2011 dalam Peningkatan Pendapatan Asli Daerah dapat dilakukan dengan dua cara yakni dengan intensifikasi dan ekstensifikasi. Kedua aspek tersebut merupakan pemecahan masalah dalam hal retribusi 
IMB yang paling relevan karena mampu mendorong baiknya masalah-masalah dalam pemungutan IMB di Kota Gorontalo.

\section{SARAN}

Berdasarkan hasil penelitian dan simpulan yang telah diuraikan di atas, maka saran penelitianiniadalahsebagai berikut:

1. Untuk meningkatkan Pendapatan asli daerah Sebaiknya Dinas terkait dalam hal ini Dinas Penanaman Modal dan Pelayanan satu Pintu (DPM-PTSP) dan Dinas Pekerjaan Umum dan Penataan Ruang (PU-PR) harus lebih tegas dalam pengawasan dan juga meningkatkan kualitas pelayanan terhadap masyarakat dengan lebih mempercepat penyelesaian proses berkas permohonan perizinan IMB, dan harus lebih kerja keras untuk mencapai target yang harus dipenuhi supaya PAD dari reribusi izin mendirikan bangunan lebih cepat terealisasi dan terlampaui dari target yang ditentukan

2. Untuk lebih mengefektifkan proses pengurusan IMB hendaknya Dinas terkait dalam hal ini DPMPTSP mengadakan kerjasama dengan pihak kelurahan dan kecamatan untuk melakukan sosialisasi terhadap masyarakat akan pentingnya IMB, sehingga dengan banyaknya masyarakat yang mengajukan IMB maka semakin banyak pula pendapatan daerah yang berasal dari retribusi IMB.

3. Pemecahan masalah harus segera diimplementasikan dimana untuk intensifikasi dapat dilakukan dengan evaluasi kebijakan, tindak lanjut rekomendasi pengawasan.

\section{DAFTAR PUSTAKA}

Adrian Sutedi. 2009. Implikasi Hukum Atas Sumber Pembiayaan Daerah dalam Kerangka Otonomi Daerah. Jakarta : Sinar Grafika

Adrian Sutedi. 2011. Hukum Pajak. Sinar Grafika : Jakarta.

Marihot Pahala Siahaan. 2010. Pajak Daerah dan Retribusi Daerah. Raja Grafindo Persada : Jakarta.

Azhar Susanto .2009,'Sistem Akuntansi Prosedur dan Metode', Yogyakarta : BPFE

Hardiansyah .2011. Kualitas Pelayanan Publik. Yogyakarta: Gava Media.

Ibrahim, Amin. 2008.Teori dan Konsep Pelayanan Publik Serta Implementasinya.Bandung : Mandar Maju.

Kadji, Yulianto. 2015. Formulasi dan Implementasi Kebijakan Publik Kepemimpinan Dan Perilaku Birokrasi Dalam Fakta Fealitas. Gorontalo. UNG Press Gorontalo

Lijan, Poltak Sinambela dkk (2006) Reformasi Pelayanan Publik,Jakarta: PT.Bumi Aksara

Moenir. 2008. Manajemen Pelayanan Umum di Indonesia.Jakarta: PT. BumiAksara. 
Ridwan Juniarso. 2009. Hukum Administrasi Negara dan Kebijakan Pelayanan Publik. Bandung: Nuansa

Santoso, Pandji, 2008, Administrasi Publik Teori dan Aplikasi Good Governance, Refika Aditama, Bandung.

Sadyohutomo, Mulyono. 2008. Manajemen Kota dan Wilayah Realita dan Tantangan. Jakarta. Bumi Aksara.

Tangkisilan Hessel Nogi S,2003, Kebijakan Publik Yang Membumi,YPAP,Yogyakarta

Triguno, (1997). Budaya Kerja, Menciptakan Lingkungan yang Kondusif untuk Meningkatkan Produktivitas Kerja. Jakarta: Golden Teravon Press.

Winarno, Budi. 2002. Teori Dan proses Kebijakan Publik.Yogyakarta: Media press.

Yamit, Zulian. 2010. Manajemen Kualitas Produk \& Jasa. Yogyakarta. Ekonesia.

Undang-Undang Nomor 23 Tahun 2014 Tentang Pemerintahan Daerah

Peraturan Daerah nomor 36 tahun 2011 tentang retribusi Izin Mendirikan Bangunan

Pasolong, Harbani. 2014.Kepemimpinan Birokrasi. Bandung : Penerbit CV.Alfabeta

Dwi, Yuni. 2008. Panduan Praktis Mengurus IMB. Yogyakarta: Penerbit Pustaka

Keputusan Menteri pendayagunaan aparatur Negara Nomor 63 tahun 2003 tentang pedoman umum penyelenggaraan pelayanan publik

Yunus, Y. 2004. Tanah dan Pengolahannya. Bandung: CV Alfabeta

Tarigan, Henry Guntur. 2009. PengkajianPragmatik. Bandung: Penerbit Angkasa

Halim, Abdul. 2004. Manajemen Keuangan Daerah. Yogyakarta: Unit Penerbit dan Percetakan Akademi Manajemen Perusahaan YKPN

Deddy Supriady, Bratakusuma dan Solihin Dadang. 2009. Otonomi Penyelenggaraan. Pemerintah Daerah, Jakarta: P.T. Gramedia Pustaka Utama

Halim, Abdul. 2007. Akuntansi Sektor Publik Akuntansi keuangan daerah,. Edisi Revisi, Jakarta, Salemba Empat

Darise, Nurlan, 2008, Akuntansi Keuangan Daerah (Akuntansi Sektor. Publik), Jakarta: PT Indeks.

Irfansyah, 2015. Kontribusi Penerimaan Retribusi Izin Mendirikan Bangunan (IMB) Dalam Peningkatan Pendapatan Asli Daerah (Pad) Di Kabupaten Penajam Paser Utara. Jurnal

Warouw, Jounica Zsezsa Sabhatini; Jullie J. Sondakh dan Stanley K. Walandouw. 2015. Pengaruh Sosialisasi Perpajakan Dan Sanksi Perpajakan Terhadap Kepatuhan Pelaporan Spt Tahunan Wajib Pajak Badan (Studi Kasus Pada KPP Pratama Manado Dan KPP Pratama Bitung). Jurnal ISSN 2303-1174 